\title{
SENSITIFITAS KURIKULUM 2013 : STIGMA SOSIAL DAN POSITIFISME PEMERINTAH
}

\author{
Halimatus Suhailah \\ Universitas Nurul Jadid \\ halima201290@gmail.com
}

\begin{abstract}
The industrial revolution marked by the term "Age Now" which is rife over the rapid advances in technology will certainly always bring negative changes to society in general and students in particular. It is characterized by negative behaviors that we often encounter in students who lack morality or morality. The reality is also indisputable because the flow of technology will increasingly develop according to modern times. One effort to filter the heavy behavior of the negative is the world of education, which is expected not only to be able to educate, provide the ability to live better in the future, but also able to improve moral eroded by the flow of negative changes. The 2013 curriculum carried by the government is an effort to realize students who are not only qualified on the cognitive side, but also excel in psychomotor and affective students. But the question is, is this positive view of $\mathrm{K}-13$ able to answer the negative stigma of parents and the problems of teachers in educating students who in fact are born from different cultures, and have been strong based on the selfishness caused by ethnicity and dissent? So, this paper raises the authors of the many problems of teachers about the 2013 Curriculum Scientific Approach with descriptive qualitative research methods through the study of library reseach.
\end{abstract}

Keywords : Sensitivity, curriculum 2013, social stigma, government positivism.

\section{PENDAHULUAN}

Ahir-ahir ini, maraknya prilaku negatif yang merusak moral dan karakter juga sering kali dikaitkan dengan latar pendidikan, seperti premanisme, penyalahgunaan narkoba, koruptor, kekerasan fisik atau kekerasan seksual yang terjadi bahkan sudah menjadi permasalahan utama dalam negri indonesia justru sangat berdampak pada kualitas pendidikan itu sendiri. Hal itu menimbulkan kesenjangan pendapat dan beberapa pertanyaan menyudutkan, yaitu apakah keunggulan positif kurikulum pendidikan telah mampu menjawab berbagai macam stigma negatif dalam pro-kontra dan serangkaian problematika pendidikan yang ditimbulkan arus perubahan jaman? 
Ataukah justru implementasi k13 justru tidak mempengaruhi output peserta didik yang secara teori kurikulum 2013 ini telah dirancang sedemikian rupa demi memenuhi standart kualitas manusia yang sholih dan sholihah. Sebagaimana jantung adalah inti dari gerak hidup manusia, maka kurikulum adalah "beare” pula bagi pendidikan. ${ }^{1}$

Menurut Juad Ihsan, pendidikan adalah proses memanusiakan manusia agar menjadi lebih baik, pengangkatan seorang manusia ketahap insani yang lebih baik itulah yang disebut mendidik. Pendidikan ialah pemanusian manusia muda. ${ }^{2}$ Pendidikan diharapkan menjadi bengkel bagi kerusakan moral yang ditimbulkan oleh modernitas jaman dan teknologi. Pada banyak opini, kebijakan pemerintah selalu mendapatkan pro-kontra, hal ini juga berlaku pada kebijakan kurikulum 2013 yang sudah tentu memilki sisi kekurangan dan kelebihan. Apa yang melatarbelakangi kurikulum 2013 ini adalah telah pasti melalui riset menyeluruh tentang kemajemukan kultur atau budaya sehingga kurikulum baru ini dirasa berguna untuk meminimalisir adanya terorisme maka pemerintah mencoba menerapkan penambahan jam mata pelajaran agama. Namun pada sisi kekurangannya, implementasi k13 ini justru dianggap tidak cocok sebab terbatasnya sarana pendidikan di pelosok desa yang sudak tak layak pakai. Hal ini juga mengherankan bagi penulis, manakala kurikulum berbasis kompetensi ini diberlakukan sementara dalam penentuan Ujian Nasional, pelajaran agama sungguh dinonaktifkan.

\section{A. Pengertian Kurikulum 2013}

Kurikulum adalah seperangkat upaya untuk menjalankan pembelajaran utamanya dalam pendidikan di sekolah. ${ }^{3}$ Sebagaimana yang dikemukakan oleh Djuwairiyah Ahmad tentang corak pendidikan di negara indonesia yaitu perencanaan sistem pendidikan di indonesia telah diatur sedemikian rupa oleh pemeritah indonesia sendiri yang terangkum jelas dalam UUD tahun 2003 yang berisi bentuk dari kurikulum, bahkan level, serta tipe kurikulum pendidikan sudah jelas tertera didalamnya. The education system in Indonesia is mainly organized by the Ministry of National Education and decreed by law Number 20 Year 2003 about the National Education System.

${ }^{1}$ Djuwairiah Ahmad, 'Understanding the 2013 Curriculum of English Teaching through the Teachers " and Policymakers "Perspectives', Ijered, 2.4 (2014), 6-15.

2 Mulyasa, Pengembangan Implementasi K13, Jakarta, Rosda, 2013, Hal 17.

3 Syafiqiyah Adhimiy Hasan Baharun, 'Curriculum Development Throught Creative Lesson Plan', Cendikia, 16.1 (2018), 41-62. 
Under Article VI, this law sets the forms, levels, and types of education that should be organized by the central government, provincial, regency, and society. UU No. 20/2003 tentang Sistem Pendidikan Nasional, yang tercantum sebuah pengertian pendidikan: "Pendidikan ialah sebuah usaha sadar dan terencana agar mewnjudkan suasana belajar serta proses pembelajaran yang efisien agar anak didik secara aktif dapat mengembangkan kemampuan dirinya sehingga memiliki kemampuan spiritual keagamaan, kemampuan pengendalian diri, kepribadian yang baik, kecerdasan yang mumpuni, akhlak dan moral yang mulia, serta skill keterampilan yang sangat diperlukan oleb dirinya, di masyaraka nantinya, serta pada bangsa dan Negara. bahkan dalam beberapa literasi juga banyak disebutkan mengenai pentingnya kurikulum bagi pendidikan, kurikulum adalah inti bagi pendidikan karna kurikulum memuat apa saja yang akan diajarkan guru kepada anak didik atau apa yang akan dipelajari anak didik untuk perkembangan dirinya yang sesuai dengan tujuan pendidikan itu sendiri. ${ }^{4}$ Kurikulum 2013 iyalah kurikulum yang ditetapkan pemerintah untuk menjadi ganti kurikulum 2006 yang sering disebut dengan kurikulum tingkat satuan pendidikan yang sudah berjalan selama 6 tahun. ${ }^{5}$ Kurikulum 2013 diharap mampu menjadikan bangsa indonesia bangsa yang bermartabat, memiiki nilai tambah dikancah internasional. Anak didik diharapkan mampu bersaing agar menjadi produktif, kreatif, inovatif dan berkarakter. ${ }^{6}$ Proses penanaman nilai karakter kepada siswa adalah dengan cara mengajak mengembangkan unsur kognitif (pikiran, pengetahuan, kesadaran), unsur afektif (perasaan), dan unsur psikomotor (perilaku). ${ }^{7}$ Kurikulum pendidikan di Indonesia menggunakan Kurikulum 2013 (K-13), yang mulai diimplementasikan pada tahun 2013, dimana peserta didik diwajibkan menguasai empat Kompetensi Inti (KI) utama, yaitu kompetensi religius, afektif, kognitif dan psikomotorik. ${ }^{8}$ Kata kurikulum berasal dari bahasa inggris yaitu, Curriculum. Hal itu berarti a running course dan dalam bahasa Perancis yakni courier yang artinya to run atau berlari. Kata itu kemudian dipakai untuk sejumlah mata pelajaran atau course yang

\footnotetext{
${ }^{4}$ Mulyasa, Pengembangan Implementasi Kurikulum 2013, Hal 20.

5 Jumadi, Pengertian Kurikulum 2013 Dan Pengembangan Kurikulum 2013, Makalah, Januari 2018, hal 12 .

${ }^{6}$ Hasan Baharun, 'Pendidikan Full Day School Dalam Perspektif Epistemologi', Potensia, 4.1 (2018), 4 <https://doi.org/10.24014/potensia.v4i1.4362>.

7 Safan Amri, Pengembangan Dan Model Pembelajaran Dalam Kurikuum 2013, Jakarta, Bumi Aksara, 2008, Hal 17.

8 Triana Asih, 'Perkembangan Tingkat Kognitif Peserta Didik Di Kota Metro', Didaktika Biologi, 2.1 (2018), 9-17.
} 
wajib ditempuh untuk mencapai gelar penghargaan dalam dunia pendidikan, yang disebut dengan ijazah.

\section{Landasan pengembangan kurikulum}

Saat ini proses pengembangan kurikulum di negara indonesia mengikuti kebijakan yang ada dalam Undang-Undang nomor 20 tahun 2003, PP nomor 19 tahun 2005, dan permendiknas nomor 22, 23, dan 24.' Berdasarkan ketetapan tersebut diatas, maka proses pengembangan kurikulum 2013 di negara Indonesia mengikuti dua langkah besar yaitu proses pengembangan kurikulum yang dilakukan oleh Pemerintah Pusat dan pengembangan yang dilakukan oleh setiap satuan pendidikan. Sebelumnya telah diberlakukan beberapa macam kurikulum, seperti kurikulum tahun 1994 dan Kurikulum tahun 2004. Kurikulum tahun 2004 disebut sebagai implementasi dari hasrat Undang-Undang pada Sistem Pendidikan Nasional (Sisdiknas) Tahun 2003. ${ }^{10}$ Sejak tahun 1945 hingga tahun 2013 kurikulum telah berganti sebanyak 10 kali yaitu tahun 1947(Rencana Pelajaran yang dirinci dalam rencana Pelajaran terurai); Tahun 1964 (Kurikulum Sekolah Dasar); Tahun 1973 (Kurikulum Proyek Perintis Sekolah Pengembangan (PPSP)); Tahun 1975 (Kurikulum Sekolah Dasar); Tahun 1984 (Kurikulum 1984); Tahun 1997 (Revisi Kurikulum 1984); Tahun 2004 (Kurikulum Berbasis Kompetensi (KBK)); dan Tahun 2006 (Kurikulum Tingkat Satuan Pendidikan (KTSP)) ${ }^{11}$. Dan saat ini adalah kurikulum 2013 yang dilandasi secara yuridis, filosofis, dan empirik.

1. Landasan Yuridis

Landasan yuridis kurikulum adalah pancasila UUD 1945 tahun 2003 tentang pendidikan nasional, peraturan pemerintah nomor 19 tabun 2005 dan Peraturan Menteri Pendidikan Nasional Nomor 23 tahun 2006 tentang Standar Kompetensi lulusan dan Peraturan Menteri Pendidikan Nasional Nomor 22 tabun 2006 tentang standar isi kurikulum. ${ }^{12}$ PP. No. 19 tahun 2005 tentang standarisasi pendidikan nasional. Dan INPRES nomor satu tabun 2010 tentang percepatan pelaksanaan prioritas pembangunan nasional, pengembangan

${ }_{9}^{9}$ Mulyasa, Pengembangan Implementasi K13, hal 29.

10 Kementrian Pendidikan dan Kebudayaan, Kurikulum 2013; Rasional, Kerangkea Dasar, Struktur, Implementasi dan Evaluasi Kurikulum, Jakarta, Kemendikbud, 2013, 06-09.

11 Zainal Arifin, Konsep Dan Model Pengembangan Kurikulum 2013, Jakarta, Rosda, Hal 11.

${ }^{12}$ Loeziana Uce, 'Realitas Aktual Praksis Kurikulum: Analisis Terhadap KBK, KTSP Dan Kurikulum 2013 Loeziana Uce’, Jurna; Ilmiyah Didaktika, 16.2 (2016), 216-29. 
penyempurnaan kurikulum pendidikan dan metode pembelajaran aktif berdasarkan nilai-nilai budaya dan bangsa untuk membentuk daya saing dalam kancah internasional dan karakter bangsa yang berkeadaban. ${ }^{13}$

2. Landasan filosofis

kedudukan filsafat dalam kurikulum adalah pedoman saat merancang, melaksanakan, atau mengembangkan kualitas pendidikan. ${ }^{14}$ Menurut Kneller amstrong (2000: 45), pengetahuan filosofi adalah hal yang mendasari, dalam konteksnya, pendidikan ialah tidak hanya digunakan agar memahami sistem pendidikan secara keseluruhan, namun untuk mengetahui secara jelas teknik-teknik aktual sebuah pembelajaran dan efektivitas metode pembelajaran. Pemahaman akan filosofi pendidikan atau khususnya pengembangan kurikulum bukan hanya menjadi ranah pada pengembang kurikulum, melainkan pula bagi guru sebagai seorang pelaksana. Guru hendaknya mengajar disertai dengan akar dan prinsip yang akurat dan memiki sifat universal. Terlebih jika hal itu dihubungkan dengan semangat KTSP. Di negara maju seperti negara Amerika Serikat, seorang guru diwajibkan memilki Personal Educational Philosophy Statement, atau pernyataan tentang filosofi pendidikan yang diyakininya. Hal-hal yang diajarkan guru di dalamnya adalah tentang pengetahuannya dalam keanekaragaman aliran filosofi, jenis-jenis aliran atau pandangan filosofi yang diyakininya, menjadi latar belakang pilihannya sebagai landasan mengajar, dan bagaimana jika kemudian ia menempatkan dirinya dalam proses pembelajaran sesuai dengan pandangan filosofi yang diyakininya tersebut. Amstrong menjelaskan tentang adanya tiga aliran dalam filosofi, yakni idealisme, realisme, dan pragmatisme. ${ }^{15}$

Filosofi memilki peran untuk membantu kita mengetahui sisi normatif dari kurikulum tentang moral, estetika, dan kriktik, kita akan terbantu menguak sisi tersebut manakala kita mampu memahami keragaman tradisi berpikir secara filosofi. Berkenaan dengan penerapan filsafat dalam kurikulum, Oliva tidak menolak adanya permasalahan yang muncul, antara lain adanya perbedaan opini pada proses pembelajaran dan kebutuhan masyarakat serta peran individu dalam masyarakat. Issu

\footnotetext{
13 Kementrian Pendidikan Dan Kebudayaan, Kurikulum 2013; Rasional, Kerangka Dasar, Struktur, Implementasi Dan Evaluasi Kurikulum, Jakarta, Kemendikbud, 2013, hal 30.

14 Zainal Arifin, Konsep Dan Model Pengembangan Kurikulum 2013, hal 21.

15 Kunandar, Penilaian Autentik; Penilaian Hasil Belajar Peserta Didik Kurikulum 2013, Jakarta, Rosda, 2013, Hal 23.
} 
lainnya adalah berkaitan dengan adanya perbedaan perbedaan interpretasi dari pernyataan-pernyataan kurikulum yang yang sudah dibuat. ${ }^{16}$ menurut amstrong ada tiga aliran dalam filosofi ini, yaitu idealisme, realisme, dan pragmatisme. ${ }^{17}$

3. Landasan Teoritis

Kurikulum 2013 dikembangkan melalui dasar teori pendidikan yang berdasarkan standar dan teori pendidikan berbasis kompetensi. Kurikulum 2013 dikembangkan atas teori "Pendidikan Berdasarkan Standar" (standard-based education), dan Teori kurikulum Berbasis Kompetensi (competency-based curriculum) ${ }^{18}$

\section{Landasan Empiris}

Kurikulum merupakan proses totalitas pengalaman peserta didik di satu satuan jenjang pendidikan untuk menguasai konten pendidikan yang dirancang dalam rencana. ${ }^{19}$ Pendidikan yang berjalan saat ini didorong oleh kepentingan untuk menajawab berbagai masalah, diantaranya adalah pesatnya perkembangan ilmu pengetahuan dan teknologi yang sangat mempengaruhi munculnya tuntutan baru dalam berbagai aspek kehidupan seperti terbentuknya sistem demokrasi, desentralisasi dan keadilan yang masuk pada sistem pendidikan. ${ }^{20}$ Indonesia adalah negara dengan berbagai macam suku, raas, budaya, dan agama yang sangat beragam, hal ini tentu sangat mempengaruhi adanya konflik yang akan meruntuhkan keutuhan bangsa. Sistem pengelolaan pendidikan yang baik tentu akan menjawab berbagai keragaman tersebut,

${ }^{16}$ Kunandar, Penilaian Autentik; Penilaian Hasil Belajar Peserta Didik Kurikulum 2013, hal 31.

${ }^{17}$ Realisme menyatakan bahwa sangatlah penting untuk mempelajari kebenaran yang kekal. Tokoh pendidikan pragmatisme yang paling terkenal adalah John Dewey Pendidikan Nasional berfungsi mengembangkan dan membentuk watak serta peradaban bangsa yang bermartabat dalam rangka mencerdaskan kehidupan bangsa (UU RI Nomor 20 tahun 2003 tentang Sistem Pendidikan Nasional). E Wara Suprihatin, 'Filosofi Sebagai Landasan Pengembangan Kurikulum', Menejemen Pendidikan, 3.01 (2007), 48-59.

${ }^{18}$ Kunandar, hal 32, pendidikan berdasarkan standart menetapkan adanya standart nasional sebagai kualitas minimum warga negara yang dirici dengan standart isi, standart proses, standart kompetensi lulusan, standart pendidik, dan standart kependidikan, sandart sarana dan prasarana, standart pengolahan, standart pembiayaan, dan standart penilaian pendidikan. Pengalaman langsung individual peserta didik merupakan hasil belajar baginya, sedangkan hasil belajar semua peserta didik menjadi hasil dari kuriulum pendidikan.

${ }^{19}$ Ktsp d a n Kurikulum And Lukmanul Hakim, 'Analisis Perbedaan Antara Kurikulum', Ilmiyah Didaktika, 17.2 (2017), 280-92 <Https://Doi.Org/10.22373/Jid.V16i1.590.5>.

20 Anin Nur Hayati, Inovasi Kurikulum, Telaah Terhadap Kurikulum, Yogyakarta, Teras, 2010 hal.18 
dan pada hakikatnya, kurikulum dapat menimalisir adanya konflik yang ditimbulkan keragaman diatas.

\section{Landasan konseptual}

- Relevansi Pendidikan (link and mach)

- Kurikulum berbasis Kompetensi dan Karakter

- Pembelajaran Konstekstual (contextual teaching and learning)

- Pembelajaran Aktif (student active learning)

- Penilaan yang Valid, Utub dan Menyeluruh. ${ }^{21}$

Prinsip-prinsip Pengembangan Kurikulum 2013

Prinsip adalah asas, keyakinan, dan pendirian. Prinsip selalu berada pada hal yang sangat penting, mendasar, perlu diperhatikan, mempunyai sifat yang memenej dan mengarahkan serta sesuatu yang selalu ada pada situasi dan kondisi yang sama. ${ }^{22}$ Adapun prinsip pengembangan kurikulum adalah sebagai berikut Berpusat Pada Potensi, Perkembangan, Kebutuhan, dan Kepentingan anak Didik serta Lingkungan didalamnya. Beragam dan Terpadu Tanggap kepada Perkembangan Ilmu dan Pengetahuan, Teknologi, dan Seni elevansi dan Kebutuhan Kehidupan yang menyeluruh dan Berkesinambungan belajar Sepanjang Hidup serta seimbang Antara Kepentingan Nasional dan Kepentingan Daerah. $^{23}$

\section{Acuan operasional kurikulum 2013}

Kurikulum 2013 disusun dengan cara memperhatikan hal-hal sebagai berikut;

- Peningkatan imtaq (iman dan taqwa) serta moral yang baik.

- Peningkatan potensi, kecerdasan dan minat sesuai tingkat prkembangan dan kemampuan peserta didik.

- Keragaman potensi (kemampuan) dan karakteristik berbagai daerah dan lingkungan.

- Tuntutan pembangunan daerah dan nasional.

- Tuntutan dunia kerja.

${ }^{21}$ Hasan Baharun, Pengembangan Kurikulum Teori dan Praktik, hal, 29-30.

22 Asyar dan Muhammad, Hakikat Fondasi Desain dan Pengembanagn Kurikulum, Fajarinter Pratama, Jakarta, 2015, hal 41.

${ }^{23}$ Asyar dan Muhammad, Hakikat Fondasi Desain dan Pengembanagn Kurikulum, hal 44. 
- Peekembangan ilmu dan pengetahuan serta teknologi sampai agama.

- Dinamika perkembangan global.

- Persatuan tingkat nasional serta nilai-nilai kebangsaan.

- Kondisi budaya masyarkat setempat.

- Kesetaraan gender.

- Karakteristk satuan kurikulum harus dikembangkan sesuai visi, misi, dan ciri khas satuan pendidikan. ${ }^{24}$

\section{Struktur dan muatan kurikulum 2013}

Seperti yang telah disebutkan bahwa K13 adalah kurikulum yang berbasis kompetensi, maka pengembangan kurikulum harus diarahkan kepada capaian kompetensi SKL. Oleh karna itu, tingkat keberhasilan belajar dan kurikulum dapat diukur dari hasil kompetensi. ${ }^{25}$ Kompetensi ini dibuat dari seiring bertambahnya usia anak didik pada kelas tertentu. Adapun rumusan kompetensi inti dapat diketahui sebagai berikut;

- Kompetensi inti-1 (KI-1) untuk kompetensi sikap spiritual.

- Kompetensi inti-2 (KI-2) untuk kompetensi inti sikap sosial.

- Kompetensi inti-3 (KI-3) untuk kompetensi ilmu pengetahuan.

- Kompetensi inti-4 (KI-4) untuk kompetensi inti keterampilan. ${ }^{26}$

Adapun dibawah ini adalah struktural tingkat persatuan pendidikan pada jenjang pendidikan dasar dan menengah yang terdapat dalam standar isi dan telah dikembangkan dengan kelompok mata pelajaran sebagai berikut;

- Kelompok mata pelajaran agaman dan akhlaq mulia

- Kelompok pelajaran bidang kewarganegaraan dan bidang kepribadian

- Kelompok bidang pelajaran ilmu dan pengetahuan serta bidang teknologi

- Kelompok bidang mata pelajran bagian estetika

- Kelompok mata pelajaran jasmani, olahraga dan kesenian. ${ }^{27}$

${ }^{24}$ Yunus Abidin, Desain Sistem Pembelajaran Dalam Konteks Kurikulum 2013, Jogjakarta, Refika Pratama, 2014, Hal 12.

${ }^{25}$ Hamalik Oemar, Kurikulum dan Pembelajaran. Jakarta: PT. Bumi Aksara, 2006, hal 57.

26 Kementrian Pendidikan dan Kebudayaan, Kurikulum 2013; Rasional, Kerangka Dasar, Struktur, Implementasi dan Evaluasi Kurikulum, Jakarta, Kemendikbud, 2013, 05-09. 
Pada kurikulum 2013, pendekatan metode pembelajaran yang dipakai adalah Pendekatan saintifiik yaitu sebuah proses pembelajaran yang dilakukan dengan dasar pengamatan ilmiyah. ${ }^{28}$ Yang dalam hal ini pendekatan saintifik dirasa mampu dipadankan dengan pembelajaran pada proses pendidikan sebagai sarana titian perkembangan sikap dan moral anak didik ataupun keteramplannya dan ilmu pengetahuan mereka. Pendekatan saintifik ini, lebih mengutamakan menalar secara induktif dari pada penalaran secara deduktif. ${ }^{29}$

Pada bentuk pembelajaran kurikulum 2013 adalah menggunakan sebuah pendekatan saintifik atau disebut juga sebagai pendekatan yang berdasarkan proses ilmiyah. Pada pendekata saintifik ini, juga mampu menggunakan beberapa cara yaitu proses pembelajaran secara kontekstual, hal ini dimaksudkan agar anak didik mampu mengetahui sendiri, memahaminya serta mampu mempraktikkan secara proses ilmiyah. ${ }^{30}$ Adapun serangkaian langkah utama dalam penerapan pembelajaran dengan pendekatan saintifik adalah;

- Mengamati; yaitu kegiatan yang dilakukan dengan membaca mata pelajaran, mendengarkan berbagai macam informasi pelajaran, menyimaknya dari berbagai sumber literasi, atau memperhatikan dengan alat atau tidak. Hal ini dilakukan untuk mengetahui seberapa besar kesungguhan anak didik dalam mempelajari mata pelajaran.

- Menanya; adalah langkah belajar dengan melakukan beberapa pertanyaan mengenai hasil yang telah diamati, atau didengarkan perihal ketidak-tahuan atau tidak mengerti akan informasi yang didapat. Bertanya ini dimaksudkan agar anak didik mampu berpikir kritis.

- Pengumpulan informasi; yaitu langkah ketiga dalam pembelajaran menggunakan pendekatan saintifik yang melalui proses eksperimen. Adalah anak didik

27 Hasan Baharun, Pengembangan Kurikulum: Teori Dan Praktik (Konsep, Prinsip, Model, Pendekatan Dan Langkah-Langkah Pengembangan Kurikulum P AI) (Yogyakarta: Cantrik Pustaka, 2017). 51

${ }^{28}$ Musfiqon, Pembelajaran Pendekatan Pembelajaran Saintifik, Sidoarjo, Nizamia Learning Center, April 2015, hal 37-38.

${ }^{29}$ Dalam penalaran secara induktif, anak didikdapat memandang masalah yang spesifik untuk dapat disimpulkan secara global, luas dan keseluruhan. Sedangkan menalar secara deduktif adalah sebaliknya yaitu, memandang masalah dari segi umum untuk dapat disimpulkan dengan spesifik. Musfiqon, Pembelajaran Pendekatan Pembelajaran Saintifik, hal 40.

30 Daryanto, Pendekatan Pembelajaran Saintifik Kurikulum 2013, Jogjakarta, Gava Media, 2014. Hal 31. 
diharapkan mampu melakukan aktifitas membaca buku-buku, mampu mengamati kejadian-kejadian dalam situasi, dan bahkan mampu melaksanakan kegiatan berupa wawancara. Hal ini diharapkan anak didik bisa jujur, berani, teliti, sopan santun, dan bertanggungjawab.

- Mengasosiasi; yaitu anak didik mampu memberikan kesimpulan mendasar terkait tiga langkah awal diatas.

- Komunikasi; adalah peserta didik diharapkan mampu menyampaikan hasil riset kesimpulannya baik dilakukan secara lisan ataupun tulisan dengan analisa yang benar. ${ }^{31}$

Secara konseptual, model pembelajaran menggunakan pendekatan saintifik ini lebih mengarah pada model belajar humanis, yaitu pembelajaran yang memberikan ruang dan waktu seluas-luasnya untuk anak didik agar memahami dan berkembang sesuai potensi dan kemampuan masing-masing anak didik. Hal itu bermakna bahwa anak didik adalah subjek pembelajaran bukan lagi sebagai objek pembelajaran. Dengan begitu, kemampuan, karakter dan nilai kognisi mereka akan semakin lebih optimal. ${ }^{32}$

\section{Stigma Sosial Kurikulum 2013}

Stigma adalah pandangan negatif sosial yang telah melekat pada seseorang yang memang dipandang telah berbeda seperti layaknya korban kejahatan, kemelaratan, atau juga seseorang yang memilki penyakit contonya HIV. ${ }^{33}$ Namun dalam literasi ini, stigma yang dimaksud oleh penulis adalah beberapa pandangan negatif masyarakat tentang kebijakan kurikulum 2013. Adapun stigma sosial ini juga dapat disetarakan dengan berbagai prolem yang melekat erat dengan kurikulum 2013. Pertama; Masalah Isi dan Kemasan, bahwa Kurikulum 2013 hanyalah memuat Pendidikan Kebangsaan dan Agama. Kedua, Kesiapan Guru. Ketiga, Kurikulum 2013 tidak Memilki Pedoman Kejurusan. Keempat Bahwa K13 Tidak Memilki Pedoman Kolaborasi Kontekstual dan Praktek yang tidak Terinci dalam Implementasi K13. ${ }^{34}$ Sedangkan menurut Anis

${ }^{31}$ Hosnan, Pendekatan Saintifik Dan Kontekstual Dalam Pembelajaran Abad 21 Kunci Sukses K13, Jakarta, Gholia Indonesia, Hal 45. hal 50 .

32 Hosnan, Pendekatan Saintifik Dan Kontekstual Dalam Pembelajaran Abad 21 Kunci Sukses K13,

33 Arikunto, Prosedur Penelitian. Jakarta: Rineka Cipta, 2010, hal 41.

34 problematika Kurikulum, D A N Kepemimpinan, And Syarwan Ahmad, 'Instruksional Kepala Sekolah', Pencerahan, 8.2012 (2014), 98-108., Sarwan Ahmad menjelaskan daam literasinya 
baswedan dalam jurnal yang ditulis oleh Inyoman ruja menyebutkan beberapa hal kekurangan kurikulum 2013 sebagai berikut;

a) Tidak adanya kajian pada penerapan kurikulum 2006 yang ahirnya berujung pada kesimpulan urgensi perpindahan kepada kurikulum 2013.

b) Tidak adanya evalasi menyeluruh kepada uji coba penerapan k13 setelah dapat setahun penerapan di sekolah-sekolah yang ditunjuk.

c) Kurikulum sudah diterapkan diseluruh sekolah pada bulan juli 2014, sementara perintah untuk melakukan evaluasi baru ditetapkan 14 oktober 2014 yaitu antara 6 hari sebelum pelantikan pelaksanaan presiden. (peraturan mentri no 159)

d) Penyeragaman tema diseluruh kelas sampai metode, isi pembelajaran, dan buku yang bersifat wajib sehingga terindikasi bertentangan dengan UU sisdiknas.

e) Penyusunan konten kompetensi inti dan kompetensi dasar tidak saksama sehingga menyebabkan ketidak selarasan.

f) Kompetensi pada bidang spiritual dan moral terkesan sangat dipaksakan sehingga mengganggu nilai substansi bidang keilmuan dan hal itu menimbulkan banyak kebingungan dan beban administratif yang berlebihan bagi para guru pendidik.

g) Metode penilaian dalam K13 sangat sempurna dan menyita banyak waktu sehingga memberatkan para guru dan hal itu malah mengalihkan fokus terhadap perhatian sepenuhnya kepada para siswa.

h) Ketidaksiapan para guru dalam menerapkan metode belajar pada kurikulum 2013 yang justru menjadi beban hal ini juga dirasakan para siswa sehingga menyebabkan waktu siswa habis di sekolah dan di luar sekolah.

i) Ketergesa-gesaan penerapan k13 menyebabkan ketidaksiapan penulisan, percetakan dan peredaran buku sehingga menyebabkan berbagai masalah di ribuan sekolah karna keterlambatan atau ketiadaan buku.

bahwa ada dikotomi pelajaran antara pelajaran umum dan agama. K13 ternyata bagian besarnya hanyalah memuat ilmu-ilmu pendidikan kebangsaan dan agama. Sedangkan ilmu sains dan biologi dijadikan satu. Hal ini bagi sebagian guru seperti ada ketidakseimbangan pelajaran. K13 yang diusung pemerintah ini dianggap tidak akan berhasil sebab kualitas guru yang tidak memadai. K13 menuntut para guru berhasil dalam tiga ranah utama, yaitu afektif, kognitif dan psikomotorik. Sedangkan pelatihan peningkatan kualifikasi guru hanya dilakukan selama 2 jam untuk kurikulum 2013. 
j) Berganti-gantinya regulasi kementrian akibat revisi yang berulang. ${ }^{35}$

Sedangkan said darius dalam literasinya menyebutkan beberapa hal yang perlu digarisbawahi pemerintah yaitu diantaranya;

Pada sistem penilaian k13 ini dianggap rumit

Pada lapangan, guru pada kenyataannya salah memahami, yakni menuntaskan segala bentuk pendidikan pada murid, dalam hal ini guru tidak peduli pemahaman anak didiknya padahal selain itu, seorang pendidik tetap melakukan tugasnya yaitu mengarahkan anak didiknya pada pemahaman yang sah.

> Ketidak-siapan mental guru sebab kurikulum ini mengharuskan guru memilki sifat kreatif yang mana tidak semua manusia memilki kemampuan yang seragam.

$>$ Ketidak-siaan guru dalam mengerti pendekatan saintifik.

> Ketidak-tahuan guru dalam menilai secara autentik.

$>$ Kebiasaan guru mengajar dengan metode konvensional.

> Kurangnya otonomi para sekolah dalam mengembangkan kurikulum pembelajarannya sendiri.

> Sedangkan tingkat keaktifan anak didik belum merata. Hal itu bisa dilihat dari penelitian empiris bahwa gen keluarga pandai akan mempengaruhi kecerdasan anak didik walau tidak 100\%. Pada banyak fakta aktual, orang tua yang memiliki ilmu terbaik, justru akan melahirkan anak-anak yang membanggakan. Cepat dalam menangkap mata pelajaran, ceapat mahir dalam menghafal serta kualitas intelektual yang memadai.

Yang paling urgen adalah sarana prasarana. Bahwa penulis saat mengajar di pedalaman bondowoso, badan sekolah masih lantai tanah, dan buku hanya ada 5 dalam satu kelas. Itu berarti setiap satu buku, akan dibaca oleh 4 anak

35 Penjelasan point peraturan mentri ini adalah pada pasal 02 ayat 02 pada peraturan mentri nomor 159 tahun 2014 menyebutkan bahwa evaluasi krikulum untuk mendapatkan informasi mengenai kesesuaian antara ide kurikulum dengan desain kurikulum serta dokumen kurikulum, kesesuaian antara dokumen kurikulum dan implementasi kurikulum dan kesesuain antara ide kurikulum, hasil kurikulum dan dampak kurikulum. Kenyataannya kurikulum 2013 diterapkan diseluruh sekolah sebelum evaluasi kesesuaian antara ide, desain, dokumen hingga dampak kurikulum. I Nyoman Ruja, 'Survey Permasalahan Implementasi Kurikulum Na- Sional 2013 Mata Pelajaran Ilmu Pengetahuan Sosial Sekolah Menengah Pertama Di Jawa Timur', Sejarah Dan Budaya, 3.N0 2 (2013), 193-99. 
didik. Sekolah dengan kondisi infrastruktur seperti ini, bagaimana mungkin akan tercipta kelas yang efisien, kreatif dan bahkan mencapai tujuan k13 yang sebenarnya?.

Banyaknya materi ajaran yang dibebankan oleh k13. Padahal tingkat konsentrasi anak didik hanya berkisar 14 menit untuk rata-rata umur 14 tahun. $^{36}$

\section{Positifisme Pemerintah}

Positifisme adalah istilah umum dalam ilmu filsafat, yang mengajarkan tentang aspek faktual ilmu pengetahuan. ${ }^{37}$ Namun dalam hal ini, sesuai perluasan kalimat era ini, positifisme adalah pandangan positif seseorang atau kelompok terkait kejadian atau hal-hal yang sedang viral serta hangat diperbincangkan. Adapun pandangan positif pemerintah pada kurikulum 2013 adalah sebagai berikut;

$\checkmark$ Ingin mengurangi segala bentuk kejahatan terorisme dengan menambah jam mata pelajaran agama.

$\checkmark$ Ingin menciptakan manusia berkarakter sebagai filter bagi kerusakan jaman, tidak mudah goyah serta memilki dasar yang kuat sebagai pedoman hidup. Bahwa kelak apapun yang terjadi, sepelik appaun taqdirnya, ia tidak akan menjadi benalu, tidak mudah korupsi atau mencuri, tidak mudah dimingimingi surga gratis dengan bunuh diri atas nama jihad.

$\checkmark$ Tuntutan dunia kerja di masa depan.

$\checkmark$ Akan meningkatkan motivasi mendidik melalui kemampuan profesi, pendidikan, soial dan individu.

$\checkmark$ Guru bukan lagi sebagai subjek utama, melainkan sebagai fasilitator.

$\checkmark$ Bahwa kurikulum 2013 ini adalah sangat sensitif pada perubahan sosial yang terjadi baik dalam tingkatan nasional, global atau tingkatan lokal.

$\checkmark$ Mewajibkan adanya remediasi secara berkala.

$\checkmark$ Tantangan globalisasi yang sedang mengancam dunia pendidikan.

${ }^{36}$ Said Darius, 'Identifikasi Kesulitan Guru Dalam Mengimplementasikan Kurikulum 2013 Dengan Pendekatan Saintifik Di Kelas Tinggi Gugus Mangga Kecamatan Jaya Baru Banda Aceh', Pesona Dasar, 2.4 (2016), 40-48.

${ }^{37} \mathrm{Hj}$ Emma and Dysmala Somantri, 'Kritik Terhadap Paradigma Positivisme', Wawasan Hukum, 28.01 (2013), 622-33. 
$\checkmark$ Mengurangi tingkat pencontekan yang dalam hal ini tercipta anak-anak yang bersifat curang, tidak percaya diri, serta tidak bertanggungjawab. Juga plagiarisme yang marak dilakukan para mahasiswa.

$\checkmark$ Agar tercipta sifat-sifat toleran dan keberagaman.

Agar memilki kecerdasan yang sesuai dengan kemampuannya.

Agar memiliki potensi komunikasi yang baik serta dapat mengemukakan pendapatnya tanpa rasa takut. ${ }^{38}$

\section{KESIMPULAN}

Kurikulum 2013 disusun atas latar belakang keadaan indonesia yang ragam perbuatan negatifnya semakin meningkat dan jauh dari moral agama. Toleransi yang semakin terkikis narasi islamisme, juga dekte negatif teroris yang selalu menyudutkan islam adalah beberapa faktor atas banyaknya permasalahan dalam negri indonesia. Hal lainnya adalah perubahan sosial dan kemajuan teknologi yang menawarkan akses tanpa batas juga sangat mempengaruhi perubahan tersebut. Maka pendidikan adalah sarana "Bengkel" terakurat untuk mencegah dan membentengi negatifisme yang mengakar pada masyarakat indonesia pada umumnya. Pemerintah dalam hal ini adalah melakukan tugasnya yaitu mengembangkan kurikulum pendidikan karakter sebagai fiter penanggulangan problem yang terus meningkat. Namun begitu, istilah yang tepat untuk menggambarkan kodisi ini adalah tiada gading ynag tak retak, bahwa kurikulum 2013 ini juga pasti memilki kekurangan yang tidak dapat dibantahkan mengingat indonesia adalah negara besar dengan brmacam-macam kultur dan agama. Pro-kontra atas kurikulum 2013 adalah hal biasa yang terjadi pada setiap kebijakan pemerintah, hal ini juga memiliki dasar yang kuat dan akurat mengenal indonesia dipelosok desa yang jauh dari jangkauan negara justru memilki sarana pendidikan yang tak layak pakai baik dari sarana-prasarana atau kualifikasi guru yang memadai. Apa yang ditawarkan k13 justru menjadi sangat tidak pas, ditambah k13 ini menggunakan pendekatan saintifik yang dalam hal ini kondisi sarana sekolah bahkan tidak memilki buku dan peralatan sekolah yang memadai. Dalam banyak literasi dan opini masyarat, k13 justru dianalogikan seperti ukuran baju, sedangkan kebutuhan 07.

38 Wakmendikbud, Konsep Dan Implementasi Kurikulum 2013, Jakarta, 14 Jaunari 2014, Hal 04- 
dan kondisi sekolah ibarat tubuh manusia. Maka setiap badan tidaklah sama dalam ukurannya mengingat pemerintah menyeragamkan ukuran tersebut. Hal ini dipandang tidaklah bijaksana. Kiranya problematika ini bisa difilter memalui pelatihan-pelatihan jangka panjang untuk peningkatan kualifikasi kemampuan guru, serta persatuan para sekolah dibawah KKM kabupaten. Sedangkan untuk masalah moral, keluarga adalah wahana terbaik mengingat ia adalah waktu terbanyak selain lingkungan sekolah. Selain itu keluarga adalah sekolah pertama untuk menciptakan lingkungan yang berpotensi baik demi terbentuknya moralitas anak yang sesuai harapan. Maka tidaklah etis jika para orang tua hanya mengandalkan para guru untuk menjadi bengkel terbaik, sedangkan orang tua berpangku tangan dalam hal itu.

\section{DAFTAR PUSTAKA}

Ahmad, Djuwairiah, 'Understanding the 2013 Curriculum of English Teaching through the Teachers " and Policymakers " Perspectives', Ijered, 2 (2014), 6-15

Baharun, Hasan, 'PENDIDIKAN FULL DAY SCHOOL DALAM PERSPEKTIF EPISTEMOLOGI', Potensia, 4 (2018), 04 <https://doi.org/10.24014/potensia.v4i1.4362>

—, Pengembangan Kurikulum : Teori Dan Praktik (Konsep, Prinsip, Model, Pendekatan Dan Langkah-Langkah Pengembangan Kurikulum PAI) (Yogyakarta: Cantrik Pustaka, 2017)

Darius, Said, 'Identifikasi Kesulitan Guru Dalam Mengimplementasikan Kurikulum 2013 Dengan Pendekatan Saintifik Di Kelas Tinggi Gugus Mangga Kecamatan Jaya Baru Banda Aceh', Pesona Dasar, 2 (2016), 40-48

Emma, Hj, and Dysmala Somantri, 'Kritik Terhadap Paradigma Positivisme', Wawasan Hukum, 28 (2013), 622-33

Hasan Baharun, Syafiqiyah Adhimiy, 'Curriculum Development Throught Creative Lesson Plan', Cendikia, 16 (2018), 41-62

Kurikulum, Ktsp D A N, and Lukmanul Hakim, 'ANALISIS PERBEDAAN ANTARA KURIKULUM', Imiyab Didaktika, 17 (2017), 280-92 <https://doi.org/10.22373/jid.v16i1.590.5>

Kurikulum, Problematika, D A N Kepemimpinan, and Syarwan Ahmad, 'INSTRUKSIONAL KEPALA SEKOLAH', PENCERAHAN, 8 (2014), 98108

Ruja, I Nyoman, 'SURVEY PERMASALAHAN IMPLEMENTASI KURIKULUM NA- SIONAL 2013 MATA PELAJARAN ILMU PENGETAHUAN SOSIAL SEKOLAH MENENGAH PERTAMA DI JAWA TIMUR', Sejarah Dan Budaya, 03 (2013), 193-99

Suprihatin, E Wara, 'Filosofi Sebagai Landasan Pengembangan Kurikulum', Menejemen Pendidikan, 3 (2007), 48-59

Triana Asih, 'Perkembangan Tingkat Kognitif Peserta Didik Di Kota Metro', 
Didaktika Biologi, 2 (2018), 9-17

Uce, Loeziana, 'REALITAS AKTUAL PRAKSIS KURIKULUM : Analisis

Terhadap KBK , KTSP Dan Kurikulum 2013 Loeziana Uce’, Jurna; Imiyah

Didaktika, 16 (2016), 216-29

Hamalik Oemar, Kurikulum dan Pembelajaran. Jakarta: PT. Bumi Aksara, 2006.

Hosnan, Pendekatan Saintifik Dan Kontekstual Dalam Pembelajaran Abad 21 Kunci Sukses K13, Jakarta, Gholia Indonesia.

Jumadi, Pengertian Kurikulum 2013 Dan Pengembangan Kurikulum 2013, Tesis, Januari 2018.

Kementrian Pendidikan dan Kebudayaan, Kurikulum 2013; Rasional, Kerangka Dasar, Struktur, Implementasi dan Evaluasi Kurikulum, Jakarta, Kemendikbud, 2013.

Kementrian Pendidikan Dan Kebudayaan, Kurikulum 2013; Rasional, Kerangka Dasar, Struktur, Implementasi Dan Evaluasi Kurikulum, Jakarta, Kemendikbud, 2013.

Kunandar, Penilaian Autentik; Penilaian Hasil Belajar Peserta Didik Kurikulum 2013, Jakarta, Rosda, 2013.

Mulyasa, Pengembangan Implementasi K13, Jakarta, Rosda, 2013.

Musfiqon, Pembelajaran Pendekatan Pembelajaran Saintifik, Sidoarjo, Nizamia Learning Center, April 2015.

Yunus Abidin, Desain Sistem Pembelajaran Dalam Konteks Kurikulum 2013, Jogjakarta, Refika Pratama, 2014.

Zainal Arifin, Konsep Dan Model Pengembangan Kurikulum 2013, Jakarta, Rosda. 